\title{
Non-Verbal Elements of the Computer-Mediated Communications in the Property Company's Instagram Accounts - A Content Analysis
}

\author{
Mochammad Surjo Koentjoro \\ \{ mochammad.koentjoro@lecturer.umn.ac.id \} \\ Universitas Multimedia Nusantara, www.umn.ac.id.
}

\begin{abstract}
In the Industrial 4.0 age, many industrial practices are combined with the new smart technology. This trend also affects the property industry by the usage of Instagram interactive social media to build partnerships and interactions with the public. In the Instagram Feed, they utilize images, infographics, and videos. The public responds with views, likes, and comments. This research was carried out in the context of social media interactions and public reaction to analyze non-verbal elements of computer-mediated communication in the medium of photographonly Instagram post. The methodology usedis a content analysis of Instagram accounts of three property Companies. The derived information is evaluated further using Linear Regression. In some cases, it was observed that content that just use images, without text and graphics, generated more likes, such that non-verbal communication can be verified in some social media environments.
\end{abstract}

Keywords: Instagram, Content Analysis, Non-Verbal Communications, Instagram Photo, Property Industry, BSD City, Alam Sutera, Gading Serpong

\section{Introduction}

\subsection{Background}

According to Schwab (2015), continuous change of engineering and business processes have been merged with the new smart technologies in the Fourth Industrial Revolution or in Industry 4.0 era. [1] One of the implications of the community's use of smart technology is the proliferation of social networking sites, which enable users to communicate with others across the network and exchange knowledge. [2],[3].

These sites can differ in form, but their standard key features are the links and the networks. [3] One of the social networking sites is Instagram, which primarily uses photos. For its followers, Instagram is more than merely a status page for the profiles they follow, but a window where they can see what the account owner is doing. [4]. Instagram itself released a video-sharing service in 2013 that encourages people to uploadaudio-visual information, not just visual content. [5].

\subsection{Problem Statements}

According to Aslam, there are 2 (two) million advertisers per month on Instagram, and there are 25 (twenty-five) million business profiles in 2020. [6] So much visual information is received by Instagram users, they tend to be picky about content to see, which ultimately makes producers scramble for consumer attention. To attract consumer attention, businesses must be able to break 
through this noise. [5] For account administrators, it is crucial to develop an effective visual strategy that can keep the attention of the user long enough until they scroll to see other images. [7]. There are several reports in the property industry that suggest this sector is lagging relativeto other sectors in terms of marketing strategies. Branding in the consumer product market, especially in Fast Moving Consumer Goods (FMCG), is more dominant and developed than property market branding, which is arguably lagging, according to research by Fah \& Cheok (2014). [8] Much of Property's branding operations revolve around promotions for sales and leasing, such as creating names and taglines, designing logos, and setting up web sites, according to Pfrang (2010). [9]

As seen in table 1, property industries lag behind other companies in terms of social networking site followers.

Table 1. Instagram official account follower numbers. (As of August 2020)

\begin{tabular}{lll}
\hline Account Owners & Number of Followers & Industry \\
\hline BSD City & 1,693 & Property \\
Alam Sutera & 16,000 & Property \\
Summarecon Serpong & 17,000 & Property \\
Vans Indonesia & $1,000,000$ & Apparels \\
Walls Ice Cream & 278,000 & Food \\
Wendy's & 111,000 & Food \\
\hline
\end{tabular}

New tactics in property marketing, including social networking platforms like Instagram, need to be implemented to be more successful.

\subsection{Literature Review}

Social Media Accounts and Branding.

Schivinski and Dabrowski (2014) suggested that Social Media Contact has a positive effect on Brand Attitude, where Brand Attitude is the assessment or appraisal of an item by an individual, including products with brands, according to Mitchell and Olson (1982). [10],[11].

Accounts on social media also affect Brand Advocacy. The more someone likes a brand on their Facebook profile, the greater their brand advocacy would be, according to Wallace et al., 2012. Keller (1993) describes Brand Advocacy as a positive tone of customer contact regarding a brand that will speed up the adoption and use. [12],[13],[14].

Based on previous research, a favorable feeling about a brand's contact (liking it) would also have a positive influence on the brand's attitude and advocacy. It is, therefore, necessary to examine and use the amount of "Likes" that contents receive on an official Instagram account as an indicator.

\section{Computer-Mediated Communication}

In the widest terms, Computer-Mediated Communication (CMC) could be any communication mediated by digital technology. [15] Moreover, CMC is not browsing the World Wide Web or downloading information, primary activity of so-called Web 1.0. Examples of CMC are interactions between individuals, whether one to one or many to many, text, sounds and images exchanged on Web 2.0, and by extension, including the Instagram framework.

In an influential essay in 1988, Rafaeli differentiates connectivity from reactivity and from interactivity. [16] Networks need an interface with people but they also need an architecture that makes it easy to communicate. These interactive networks, once formed, have their own history, and relationships develop across such a history. The two-way dialog itself does not ensure 
interactivity. Instead, an interaction or answer must develop into a connection where one concept becomes a meaning for another. In Instagram, communication happens when an account, whether business or personal, posts a specific content to be seen, liked, and commented on by the account's followers, hence an exchange happened and a relationship is formed.

\section{Non-Verbal Elements of the Computer-Mediated Communications}

Texts were dominant in the early days of computer-mediated communication (CMC). But recent developments provide various options for enhancing or replacing text messages. These include social networks like Instagram and Snapchat that share photos. Elder (2018) shows the positive potential of human wellbeing and interpersonal communication for nonverbal elements of CMC, including emoji and other non-verbal elements. They can be used to concentrate and direct, convey challenging emotions and understand them. Non-verbal elements of communication influence affective and emotional states. [17].

Non-Verbal Elements in Computer-Mediated Communication utilizes the concept of Joint Attention, which is a significant societal circumstance. Joint attention happens when two or more individuals turn their attention to the same object and, are each conscious that it has been witnessed jointly [18]. One individual may invite another to engage by pointing out, following another's glance, saying, "Look here," or a variety of other methods. By allowing others to take part in the same process as themselves, connections are established.

In Instagram, this can be achieved by uploading a post of just a photograph without the addition of any texts or other artificial visual elements. By exchanging photographs using digitally mediated communication, senders are encouraging receivers to participate in joint attention. The importance of this affordability is not to undervalue. Recall Aristotle's argument that friends "share their lives" by sharing "thinking and communicating." Joint attention may be instrumentally useful by exchanged images. It will help people submit information and plan their activities.

Visual modes of communication will become more prevalent and more critical to societal functioning than verbal modes in the 21 st century. Visual media are more accessible, less costly, and society gradually promotes digital media for entertainment, education, and communication. Scholars reflected on the growing visualization of communication in the 20th century, that the study of the communicative role and the rhetorical capacity of images has significantly grown over the last two decades. [15]

In the context of Non-Verbal Element of Computer-Mediated Communication in Property Company Instagram accounts, this study aims to investigate the effects of photo-only Instagram contents (non-verbal) on the public response (likes), compared to Infographics and Image Compositions (Pictures with texts (verbal)).

\section{Methodology}

\subsection{Content Analysis}

In this research, Content Analysis was used to gain insight into the Instagram accounts' interactions, especially those related to Non-Verbal elements of the Computer-Mediated Communications. Furthermore, Linear Regression was used to analyze the relationship between the concepts studied, namely the Non-Verbal Posts, and the "Like" they get.

For this content analysis, data were obtained from 3 (three) Property Industry Companies' Instagram accounts with a total of 261 posts from June $1^{\text {st }}, 2020$ to July $31^{\text {st }}, 2020$. BSD City, 
Alam Sutera Realty, and Summarecon Serpong are three adjacent property developers with businesses based in Tangerang City and Southern Tangerang City, Banten Province, Indonesia. During the monitoring period, BSD City uploaded 52 (fifty-two) posts, Alam Sutera Realty uploaded 83 (eighty-three) posts, and Summarecon Serpong uploaded 127 (one hundred and twenty-seven) posts in their respective Instagram accounts.

Based on the observations referred to in the earlier sections and the particular characteristics and audience of each account, three hypotheses are proposed:

- H1: Photograph-only contents (Non-verbal) have more influence on BSD City Instagram users than contents consisting photographs with text and, or graphics.

- H2: Photograph-only contents (Non-verbal) have more influence on Alam Sutera Realty Instagram users than contents consisting photographs with text and, or graphics.

- H3: Photograph-only contents (Non-verbal) have more influence on Summarecon Serpong Instagram users than contents consisting photographs with text and, or graphics.

\subsection{Coding}

For analysis, Coding for Non-Verbal Elements was developed as independent variables (PHC). Binary coding ( 0 and 1$)$ is used here. The number 0 represents the media that is "verbal", in this case, infographics and image composition posts, and the number 1 for "non-verbal" media, in this case, photo-only posts. The resulting coding is shown in table 2.

Table 2. Coding.

\begin{tabular}{llcl}
\hline Variable & Classification & Coding & Operationalization \\
\hline Non-Verbal Element & "Verbal" Media & 0 & Posts featuring Photograph only. \\
& "Non-Verbal" Media & 1 & $\begin{array}{l}\text { Posts featuring Infographics and/or } \\
\text { Image Composition. }\end{array}$ \\
\hline
\end{tabular}

\section{Finding and Discussion}

\subsection{Findings and Analysis}

The results were:

Table 3. The ratio of Verbal and Non-Verbal Instagram contents and Like: (June 1st - July 31st, August 2020).

\begin{tabular}{lllllll}
\hline & \multicolumn{3}{c}{ Contents } & \multicolumn{3}{c}{ Like } \\
\cline { 2 - 7 } & Verbal (0) & $\begin{array}{l}\text { Non-Verbal } \\
(1)\end{array}$ & Total Posts & Verbal (0) & $\begin{array}{l}\text { Non-Verbal } \\
(1)\end{array}$ & Total Likes \\
\cline { 2 - 7 } & $33(87 \%)$ & $5(13 \%)$ & 38 & $402(59 \%)$ & $282(41 \%)$ & 684 \\
$\begin{array}{l}\text { BSD City } \\
\text { Alam Sutera Realty55(83\%) }\end{array}$ & $11(17 \%)$ & 66 & $1992(81 \%)$ & $455(19 \%)$ & 2447 \\
$\begin{array}{l}\text { Summarecon } \\
\text { Serpong }\end{array}$ & $55(51 \%)$ & $52(49 \%)$ & 107 & $2902(35 \%)$ & $5286(65 \%)$ & 8188 \\
\hline
\end{tabular}

While in Alam Sutera Realty's account, $83 \%$ of their posts were Verbal, which gets $81 \%$ of the likes, with their Non-verbal posts, which amounted to $17 \%$ of their 684 posts, gets $19 \%$ of the likes. In the case of Summarecon Serpong's account, $51 \%$ of their posts were Verbal, which gets $35 \%$ of the likes, with their Non-verbal posts which amounted to $49 \%$ of their 684 posts, gets $65 \%$ of the likes. 


\section{BSD City}

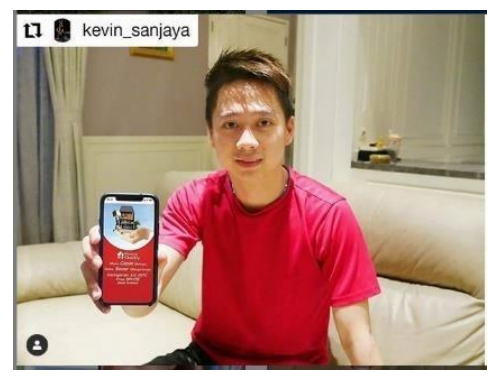

Fig. 1. The post with the most Like (190) in BSD City's account observed during research, a Non-Verbal post featuring an endorsement from Kevin Sanjaya, a national athlete.

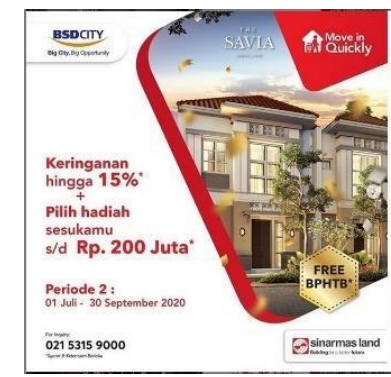

Fig. 2. The post with the least Like (3) in all accounts observed during research, a Verbal post belonging to BSD City featuring an image composition advertisement.

From the resulting data shown in Table 3, in BSD City's account, as much as $87 \%$ of their posts were Verbal, which gets $59 \%$ of the likes, with their Non-verbal posts amounted to only $13 \%$ of their 684 posts but gets as much as $41 \%$ of the likes. These numbers show that Non- Verbal posts have more strength to generate more likes per posts than Verbal ones.

Table 4 Mean (BSD City, June 1st - July 31st data, August 2020)

\begin{tabular}{lrrrr}
\hline MRL & Mean & N & \multicolumn{2}{c}{ Std. Deviation } \\
\hline PHC & 12.18 & 33 & 7.485 \\
\hline (Verbal) & 56.40 & 5 & 75.149 \\
1 (Non-Verbal) & 18.00 & 38 & 29.807 \\
Total & & 38 & \\
\hline
\end{tabular}

Table 4 (Mean) shows that for every Verbal content (PHC Coding $=0$ ), there are an average of 12.18 likes, and for every Non-Verbal content (MF Coding $=1$ ), there are an average of 56.40 likes, which is much higher than Verbal posts' average likes

Overall, for every content on BSD City Official Instagram, there is an average of 18 likes. 
Table 5 Linear Regression (BSD City, June 1st - July 31st data, August 2020)

\begin{tabular}{lrrrr}
\hline Model & R & R Square & Adjusted R Square \\
\hline 1 & $.508^{\mathrm{a}}$ & .258 & .238 \\
\hline
\end{tabular}

a. Predictors: (Constant), PHC

Table 5 (Linear Regression) shows the R-value representing the correlation coefficient, which is 0.508 . It can be interpreted that the correlation between the two research variables is strong. This table also shows the R Square value of 0.258 , which can be interpreted that the Non-Verbal Element independent variable (PHC) has a $25.8 \%$ contribution effect on the dependent variable Like (MRL), while the other $74.2 \%$ is influenced by other factors. [19],[20],[21]

Table 6 Correlations: (BSD City, June 1st - July 31st data, August 2020)

\begin{tabular}{llll} 
& PHC & MRL \\
\hline PHC & Pearson Correlation & 1 & $.508^{* *}$ \\
& Sig. (2-tailed) & .001 \\
& N & 38 & 38 \\
\hline$* *$ Correlation is significant at the 0.01 level (2-tailed).
\end{tabular}

Table 6 (Correlations) shows a Significance value (Sig.) of 0.001, with the provision that with the Sig. $<0.05$, then the regression model is linear. Thus, the regression equation model based on the research data is significant; that, the linear regression model has met the linearity criteria. [21]

Therefore, hypothesis $\mathrm{H} 1$ is confirmed, photograph-only contents (Non-verbal) have more influence on BSD City Instagram users than Verbal contents.

\section{Alam Sutera Realty}

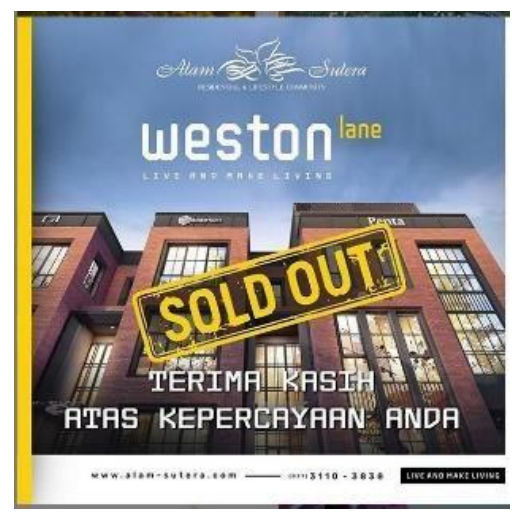

Fig. 3. The post with the most Like (102) in Alam Sutera Realty's account observed during research, a Verbal post featuring an announcement/advertisement about a product being soldout. 


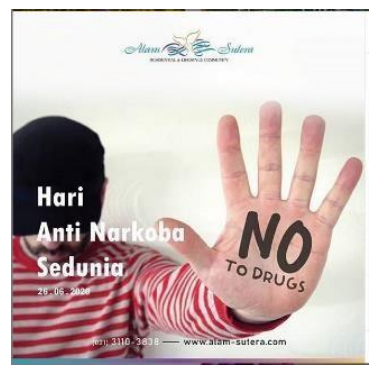

Fig. 4. The post with the least Like (15) in Alam Sutera Realty's account observed during research, a Verbal post featuring International Anti-Drug Day Public Service Announcement.

From the resulting data shown in Table 3, in BSD City's account, $83 \%$ of their posts were Verbal, which gets $81 \%$ of the likes, with their Non-verbal posts, which amounted to $17 \%$ of their 2447 posts, gets $19 \%$ of the likes. These numbers show that in the case of Alam Sutera Realty, the Contents are proportionate with the Likes.

Table 7 Mean (Alam Sutera Realty, June 1st - July 31st data, August 2020)

\begin{tabular}{lr|rrr}
\hline MRL & Mean & N & \multicolumn{2}{c}{ Std. Deviation } \\
\hline PHC & 36.22 & & 55 & 14.249 \\
\hline (Verbal) & 41.36 & & 11 & 18.554 \\
1 (Non-Verbal) & 37.08 & & 66 & 15.012 \\
Total & &
\end{tabular}

Table 7 (Mean) shows that for every Verbal content (PHC Coding $=0$ ), there is an averageof 36.22 likes, and for every Non-Verbal content (MF Coding =1) there is an average of 41.36 likes, only a little higher.

Overall, for every content at Alam Sutera Realty Instagram, there is an average of 37.08 likes.

Table 8 Linear Regression (Alam Sutera Realty, June 1st - July 31st data, August 2020)

\begin{tabular}{lllll}
\hline Model & \multicolumn{1}{c}{ R } & R Square & Adjusted R Square & \\
1 & $.129^{\mathrm{a}}$ & .017 & & .001 \\
\hline b. & Predictors: (Constant), PHC & &
\end{tabular}

Table 8 (Linear Regression) shows the R-value representing the correlation coefficient, which is 0.129 . It can be interpreted that the correlation between the two research variables is weak. This table also shows the R Square value of 0.017, which can be interpreted that the Non-Verbal Element independent variable (PHC) has a 1.7\% contribution effect on the dependent variable Like (MRL), while the other $98.3 \%$ is influenced by other factors. [19],[20],[21] 
Table 9 Correlations: (Alam Sutera Realty, June 1st - July 31st data, August 2020)

\begin{tabular}{llr|r} 
& PHC & \multicolumn{2}{c}{ MRL } \\
\hline PHC & Pearson Correlation & 1 & .129 \\
& Sig. (2-tailed) & & .303 \\
& N & 66 & 66 \\
\hline
\end{tabular}

Table 9 (Correlations) shows a Significance value (Sig.) of 0.303 , with the provision that with the Sig. <0.05, then the regression model is linear. Thus, the regression equation model based on the research data is not significant. That the linear regression model has not met the linearity criteria. [21]

Therefore, hypothesis $\mathrm{H} 2$ is not confirmed. Photograph-only contents (Non-verbal) do not have more influence on Alam Sutera Realty Instagram users than Verbal contents.

\section{Summarecon Serpong}

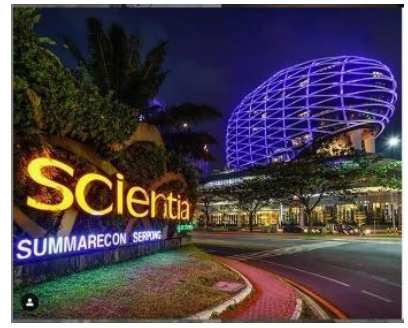

Fig. 5. The post with the most Like (214) in all accounts observed during research, a Non- Verbal post belonging to Summarecon Serpong in the form of a Nighttime photography of aspot in the Company's area.

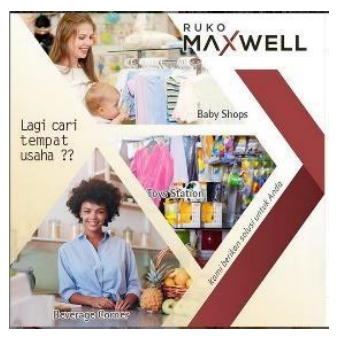

Fig. 6. The post with the least Like (22) in Summarecon Serpong account observed during research, a Verbal post of a product advertisement in the form of image composition.

From the resulting data shown in Table 3, in BSD City's account, 51\% of their posts were Verbal, which gets only $35 \%$ of the likes, with their Non-verbal posts, which amounted to $49 \%$ of their 8188 posts, gets as much as $65 \%$ of the likes. These number shows that NonVerbal posts have more strength to generate more likes per posts than Verbal ones. 
Table 10 Mean (Summarecon Serpong, June 1st - July 31st data,

August 2020)

\begin{tabular}{lr|rr}
\hline MRL & Mean & $\mathrm{N}$ & \multicolumn{2}{c}{ Std. Deviation } \\
\hline PHC & 51.47 & 55 & 25.082 \\
\hline (Verbal) & 101.65 & 52 & 40.394 \\
1 (Non-Verbal) & 75.86 & 107 & 41.719 \\
Total & & & \\
\hline
\end{tabular}

Table 10 (Mean), shows that for every Verbal content (PHC Coding $=0$ ), there is an average of 51.47 likes, and for every Non-Verbal content (MF Coding $=1)$ there is an average of 101.65 likes, or almost twice of Verbal posts' average likes.

Overall, for every content at Summarecon Serpong Official Instagram, there is anaverage of 75.86 likes.

Table 11 Linear Regression (Summarecon Serpong, June 1st - July 31st data,August 2020)

\begin{tabular}{lllll}
\hline Model & \multicolumn{1}{c}{$\mathrm{R}$} & $\mathrm{R}$ Square & Adjusted R Square & \\
\hline 1 & $.604^{\mathrm{a}}$ & .365 & & .359 \\
\hline
\end{tabular}

c.

Predictors: (Constant), PHC

Table 11 (Linear Regression) shows the R-value representing the correlation coefficient, which is 0.604 . It can be interpreted that the correlation between the two research variables is strong. This table also shows the R Square value of 0.365 , which can be interpreted that the Non-Verbal Element independent variable (PHC) has a 36.5\% contribution effect on the dependent variable Like (MRL), while the other $63.5 \%$ is influenced by other factors. [19],[20],[21]

Table 12 Correlations: Summarecon Serpong, June 1st - July 31st data, August 2020)

\begin{tabular}{llrr} 
& PHC & MRL \\
\hline PHC & Pearson Correlation & 1 & $.604^{* *}$ \\
& Sig. (2-tailed) & 107 & .000 \\
& N & 107 \\
\hline$* *$ Correlation is significant at the 0.01 level (2-tailed).
\end{tabular}

Table 12 (Correlations) shows a Significance value (Sig.) of 0.000 , with the provision that with the Sig. $<0.05$, then the regression model is linear. Thus, the regression equation model based on the research data is significant. That the linear regression model has met the linearity criteria.[21]

Therefore, the hypothesis H3 is confirmed, photograph-only contents (Non-verbal) have more influence on Summarecon Serpong Instagram users than Verbal contents.

\subsection{Comparisons to Previous Research}

Kusumasondjaja's research [5] found how certain types of content uploaded by Brand owners would typically got more likes or responses than other types of content. A phenomenonaffirmed by this research. Elder's study [17] suggested that the popularity of Non-Verbal Elements of $\mathrm{CMC}$ is due to their ability to increase emotional expression and responsiveness; a finding that can be used to develop this research. 


\section{Conclusion}

The Non-Verbal Elements of the Computer-Mediated Communication can affect the Social Media Pages (Instagram) of a property industry corporation, according to the research findings. This can be seen from the Non-Verbal contents of BSD City and Summarecon Serpong. This can be used as a guide in the management of social media pages, particularly Instagram, in the real estate industry to better connect with the public. The fact that Alam Sutera has not shown the same results must be further explored by observing other variables and using other methodologies.

\subsection{Recommendations Academical Implications}

The analysis needs to be continued by exploring whether this phenomenon exists in other property companies in order to provide a complete picture, and to further explore what other causes, principles, and theories can enhance business communication and public participation.

\section{Managerial Implications}

BSD City

While the hypothesis on this Company's account has been confirmed, the findings also show the relatively small number of Instagram posts in BSD City account compared to other companies, and these findings can guide the style of posts that need to be uploaded for good public response.

Alam Sutera

- The Company's Non-Verbal Instagram contents had little effect on gaining more Likes from the visitors, a management path worth pursuing.

- From the preliminary observation, the number of Likes produced by the Company's posts does not fluctuate too much, so it is recommended to research the strength of the Company in Brand Equity and Brand Attitude.

Summarecon Serpong

While the hypothesis on this Company's account has been confirmed, it was also observedthat the Company frequently invites users to submit their photos to post at the Official Instagramfeed, which from preliminary observation, generates a substantial number of Likes, so this practice can be expanded to include high-quality videos.

\section{References}

[1] Schwab, K. The Fourth Industrial Revolution. What It Means, and How to Respond. https://www.foreignaffairs.com/articles/2015-12-12/fourth-industrial-revolution. 2015. Accessed on July 6, 2020.

[2] Tsiotsou, R. H. The role of social and parasocial relationships on social networking sites loyalty. Computers in Human Behavior. 2015, 48401-414.

[3] Ward, J. A Content Analysis of Celebrity Instagram Post and Parasocial Interaction. Elon Journal of Undergraduate Research in Communications. 2016.

[4] Stever, G. S. \& Lawson, K. Twitter as a Way for Celebrities to Communicate with Fans: Implications for the Study of Parasocial Interaction, 2013. North American Journal of Psychology, Vol. 15, No.2,. 
[5] Kusumasondjaja, S. Exploring the Role of Visual Aesthetics and Presentation Modality in Luxury Fashion Brand Communication on Instagram. 2020. Journal of Fashion Marketing and Management: An International Journal, Vol. 24 No. 1, pp 1531.

[6] Aslam,S. Instagram by the Numbers: Stats, Demographics, \& Fun Facts. https://www.omnicoreagency.com/instagram-statistics /,2020. Accessed September 13, 2020.

[7] Bhandari, U., Chang, K., \& Neben, T. Understanding the impact of perceived visual aesthetics on user evaluations: an emotional perspective, Information \& Management. 2019. Vol. 56 No. 1.

[8] Fah, C. F. \& Cheok, J. Importance of Branding for Property Development in Malaysia. 2013. Sunway Academic Journal 5.

[9] Pfrang, D. C. Property Brands - Developing A Strategic Branding Model For The Real Estate Business. 17th Annual European Real Estate Society Conference. 2010. Milan, Italy.

[10] Schivinski, B. \& Dabrowski, D. The effect of social media communication on consumer perception of brands. GUT Faculty of Management and Economics Working Paper Series A (Economics, Management, Statistics) No.12/2013 (12)

[11] Mitchell, A. A. \& Olson, J. C. Are Product Attribute Beliefs the Only Mediator of Advertising Effects on Brand Attitude? Journal of Marketing Research, 1981. Vol. 18, No. 3, pp. 318-332.

[12] Wallace, E., Buil, I., \& de Chernatony, L. Facebook 'friendship' and Brand Advocacy, Journal of Brand Management, 2012. Vol. 20, 2, pp. 128-146

[13] Keller, K.L. Conceptualizing, measuring and managing customer-based brand equity. Journal of Marketing 57(1) 1993: pp. 1-22

[14] Kemp, E., Childers, C. Y., Williams, K. H. Place Branding: Creating Self-brand Connections and Brand Advocacy, Journal of Product Brand \& Management. 2012

[15] Littlejohn, S. W. \& Foss, A. Encyclopedia of Communication Theory, SAGE Publications, Inc, 2009, pp. 161-164.

[16] Rafaeli, S. Interactivity: From new media to communication. Sage Annual Review of Communication Research. 1988.

[17] Elder, A. M., "What Words Can't Say: Emoji and other non-verbal elements of technologically- mediated communication", Journal of Information, Communication and Ethics in Society, 2018, Vol. 16 No. 1, pp. 2-15.

[18] Moore, C. and Dunham, P.J. (Eds). Joint Attention: Its Origins and Role in Development, 1995. Lawrence Erlbaum Associates.

[19] The jamovi project. jamovi. (Version 1.2) [Computer Software]. 2020. Retrieved from https://www.jamovi.org on October 7, 2020

[20] R Core Team. R: A Language and environment for statistical computing. (Version 3.6) [Computer software]. 2019. Retrieved from https://cran.r-project.org/ on October 7, 2020

[21] Hidayat, Anwar. Regresi Linear Sederhana dengan SPSS. https://www.statistikian.com/2012/08/regresi-linear-sederhana-denganspss.html\#Interprestasi_Regresi_Linear_Sederhana_dengan_SPSS. 2012. Accessed on August 15, 2020. 